\title{
First Pandemic H1N1 Outbreak from a Pig Farm in Italy
}

\author{
Ana Moreno ${ }^{*}, 1$, Livia Di Trani ${ }^{2}$, Loris Alborali ${ }^{1}$, Gabriele Vaccari ${ }^{2}$, Ilaria Barbieri ${ }^{1}$, \\ Emiliana Falcone ${ }^{2}$, Enrica Sozzi ${ }^{1}$, Simona Puzelli ${ }^{2}$, Gaetana Ferri ${ }^{3}$ and Paolo Cordioli ${ }^{1}$ \\ ${ }^{1}$ Istituto Zooprofilattico Sperimentale della Lombardia e dell'Emilia Romagna, Brescia, Italy \\ ${ }^{2}$ Istituto Superiore di Sanità, Rome, Italy \\ ${ }^{3}$ Ministero della Salute, Rome, Italy
}

\begin{abstract}
The first outbreak of the pandemic H1N1 virus in a swine breeder farm in Italy in November 2009 was reported. Clinical signs observed in sows included fever, depression, anorexia and agalactia, while in piglets diarrhoea and weight loss. The morbidity in sows was approximately $30 \%$ and the accumulated mortality rate was similar with those usually reported in piggeries $(<10 \%)$. Virus was isolated from piglets $(\mathrm{A} / \mathrm{Sw} / \mathrm{It} / 290271 / 09)$ and the sequencing of the whole genome was then performed. Comparison with all (H1N1)v sequences available in GenBank shows A/Sw/It/290271/09 three unique amino-acid (aa) changes in PB2 (S405T), PB1 (K386R) and PA (K256Q), not yet associated to any well characterized phenotype markers of Influenza viruses. All eight aa at positions representing the socalled species specific swine-human signatures, found in both swine and in the pandemic H1N1v, are also present. The M2 protein displays the $\mathrm{C} 55 \mathrm{~F}$ and the PA protein the S409N substitutions, both corresponding to enhanced transmission phenotype markers. Phylogenetic analysis showed that the virus was genetically related to the pandemic H1N1 virus. In addition, serological samples were collected from 40 sows, of which 20 resulted positive to the pandemic H1N1 virus by HI test proving a virus circulation in the farm.
\end{abstract}

Keywords: Pandemic H1N1 virus, swine, genomic characterization, Italy.

Influenza viruses cause annual epidemics and occasional pandemics spreading worldwide and infecting a large proportion of the human population. During April 2009, a novel H1N1 (H1N1)v influenza A virus was identified as the cause of the present flu pandemic [1]. This virus was found to be genetically and antigenically unrelated to the seasonal human influenza and was generated as a quadruple reassortant, possessing genes from Euro-Asiatic and American lineages of swine influenza, as well as avian and human influenza genes [2]. In Italy, swine influenza monitoring programs, based on genome detection, virus isolation and sequencing of all respiratory forms, have been applied since the nineties, especially in North Italy where more than $75 \%$ of the pig population is located. Responding to the emergence of the new pandemic virus and consequently to the recent reports about human to animal transmission [3, 4], testing for the $(\mathrm{H} 1 \mathrm{~N} 1) \mathrm{v}$ was also performed on all the swine samples resulted positive for type A influenza.

This paper describes the isolation and complete genomic characterization of the first $(\mathrm{H} 1 \mathrm{~N} 1) \mathrm{v}$ detected in a pig farm in Italy. The genome sequence of the isolate was determined and phylogenetic analysis was conducted by comparing HA and NA sequences with selected Influenza A pandemic, swine and avian viruses.

\footnotetext{
*Address correspondence to this author at the Istituto Zooprofilattico Sperimentale della Lombardia e dell'Emilia Romagna, Via Bianchi 9, 25124 Brescia, Italy; Tel: +39 030 2290361; Fax: +39 030 2290535;

E-mail: anamaria.morenomartin@izsler.it
}

In November 2009, a 1264 swine breeder farm located in Lombardia region (Northern Italy) experienced lower sow reproduction performances in farrowing units. Clinical signs observed in sows included fever, depression, anorexia and agalactia, while in piglets diarrhoea and weight loss. The morbidity in sows was approximately $30 \%$ and the accumulated mortality rate was similar to those usually reported in piggeries $(<10 \%)$. Swine influenza vaccination has not been applied. Nine dead piglets and four nasal swabs from sows were submitted to the diagnostic laboratory. Out of these, 8 piglets showed catarrhal enteritis whereas the last one presented pneumonia with a purple area of consolidation in the apical lobes. Lung homogenates from the 8 piglets without lung lesions were performed in two separate pools of 4 piglets each one, while lung from piglet 9 was tested alone. Clinical specimens were screened for the presence of influenza A viruses by real time RT-PCR [5]. Positive samples were further tested for the $(\mathrm{H} 1 \mathrm{~N} 1) \mathrm{v}$ by real time RT-PCR (rt RT-PCR), according to the CDC procedure [6]. All samples were also cultured using different media for the most common swine respiratory bacterial pathogens and tested for detection of Porcine reproductive and respiratory syndrome virus (PRRSV), Porcine circoviruses type 2 (PCV2) and Mycoplasma hyopneumoniae by using RT-PCR, multiplex PCR and PCR assays respectively [7-9]. The first pool (animals 1-4) and piglet 9 resulted positive to the type A influenza as well as for $(\mathrm{H} 1 \mathrm{~N} 1) \mathrm{v}$ assay. Only PRRSV European strain was detected from the first pool, whereas other samples resulted negative for the tested pathogens.

For virus isolation, positive samples were applied onto Madin-Darby canine kidney (MDCK) cells, Caco-2 cells and 
inoculated into SPF chicken embryonated eggs (CEE). The strains could be isolated from pool 1 and piglet 9 either on cell cultures or CEE (A/Sw/It/290271/09 and $\mathrm{A} / \mathrm{Sw} / \mathrm{It} / 308288 / 09$, respectively).

For genomic sequencing viral RNA was extracted form allantoic fluid of A/Sw/It/290271/09 using QIAamp ViralRNA Mini Kit (Qiagen, Hilden, Germany). SuperScript III One-Step RT-PCR System with Platinum Taq High Fidelity (Invitrogen Carlsbad, CA, USA) was used to perform RT-PCR of 46 amplicons representing the entire viral genome using the Influenza A (H1N1) genome Primer Set (Applied Biosystems, Foster City, CA, USA). Sequencing reactions were performed using BigDye Terminator Cycle Sequencing kit v3.1 and resolved by an ABI 3130 DNA automatic sequencer. Multiple sequence alignments were made using ClustalW and maximum parsimony phylogenetic trees were created using MEGA4 [10].

GenBank accession numbers of the eight genes are: CY053619 (HA), CY053621 (NA), CY053622 (M), CY053620 (NP), CY053618 (PA), CY053617 (PB1), CY053616 (PB2), CY053623 (NS1).
Full genome sequencing of A/Sw/It/290271/09 confirms a very high similarity through the viral genome to the pandemic virus circulating in humans. Comparison with all (H1N1)v sequences available in GenBank shows in $\mathrm{A} / \mathrm{Sw} / \mathrm{It} / 290271 / 09$ three unique amino-acid (aa) changes in PB2 (S405T), PB1 (K386R) and PA (K256Q), not yet associated to any well characterized phenotype markers of Influenza viruses. All eight aa at positions representing the so-called species specific swine-human signatures [11], found in both swine and in the pandemic H1N1v, are also present. The M2 protein displays the $\mathrm{C} 55 \mathrm{~F}$ and the PA protein the $\mathrm{S} 409 \mathrm{~N}$ substitutions, both corresponding to enhanced transmission phenotype markers [12].

Phylogenetic analysis was based on complete open reading frames of $\mathrm{HA}$ and NA sequences of A/Sw/It/290271/09 and representative H1 and N1 subtypes of human, avian and swine origin, mostly isolated in Italy in the last decade (Figs. 1, 2). The HA phylogenetic tree shows that the italian avian and swine isolates from 1998 to 2009, form a clearly distinct lineage including two different clusters of H1N1 (avian and swine viruses) and H1N2 swine strains. The N1 phylogenetic analysis revealed that NA genes closest to SW/IT/290271/09 and (H1N1)v were all

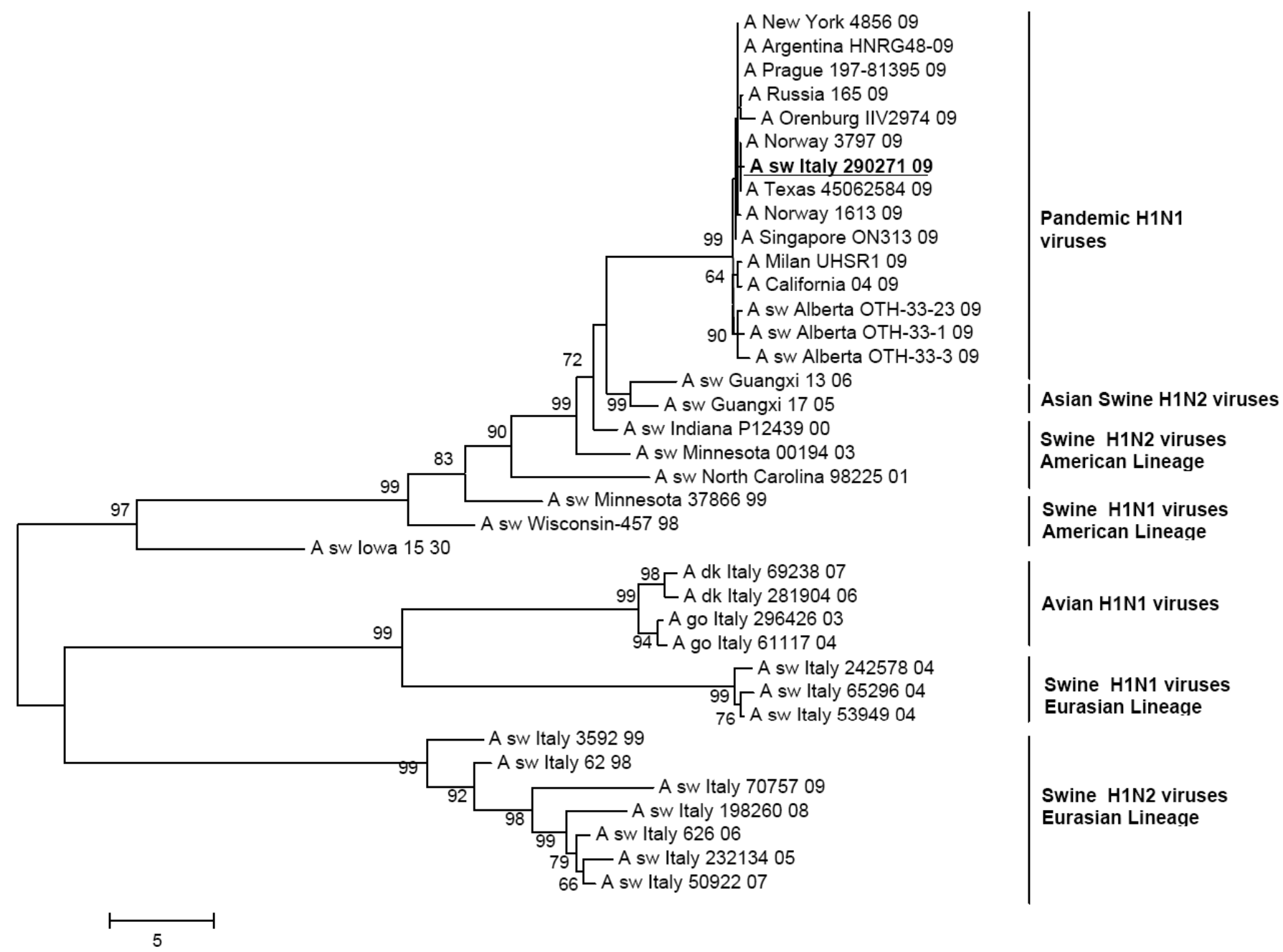

Fig. (1). Phylogenetic relationship of the HA gene of the swine H1N1 pandemic Italian isolate (A/sw/Italy/290271/2009 H1N1) with other Italian SIV and AIV viruses and database retrieved H1N1 and H1N2 swine and human viruses. The unrooted tree was created by maximum parsimony method and bootstrapped with 500 replicates. Only bootstrap values higher than $70 \%$ are shown. 


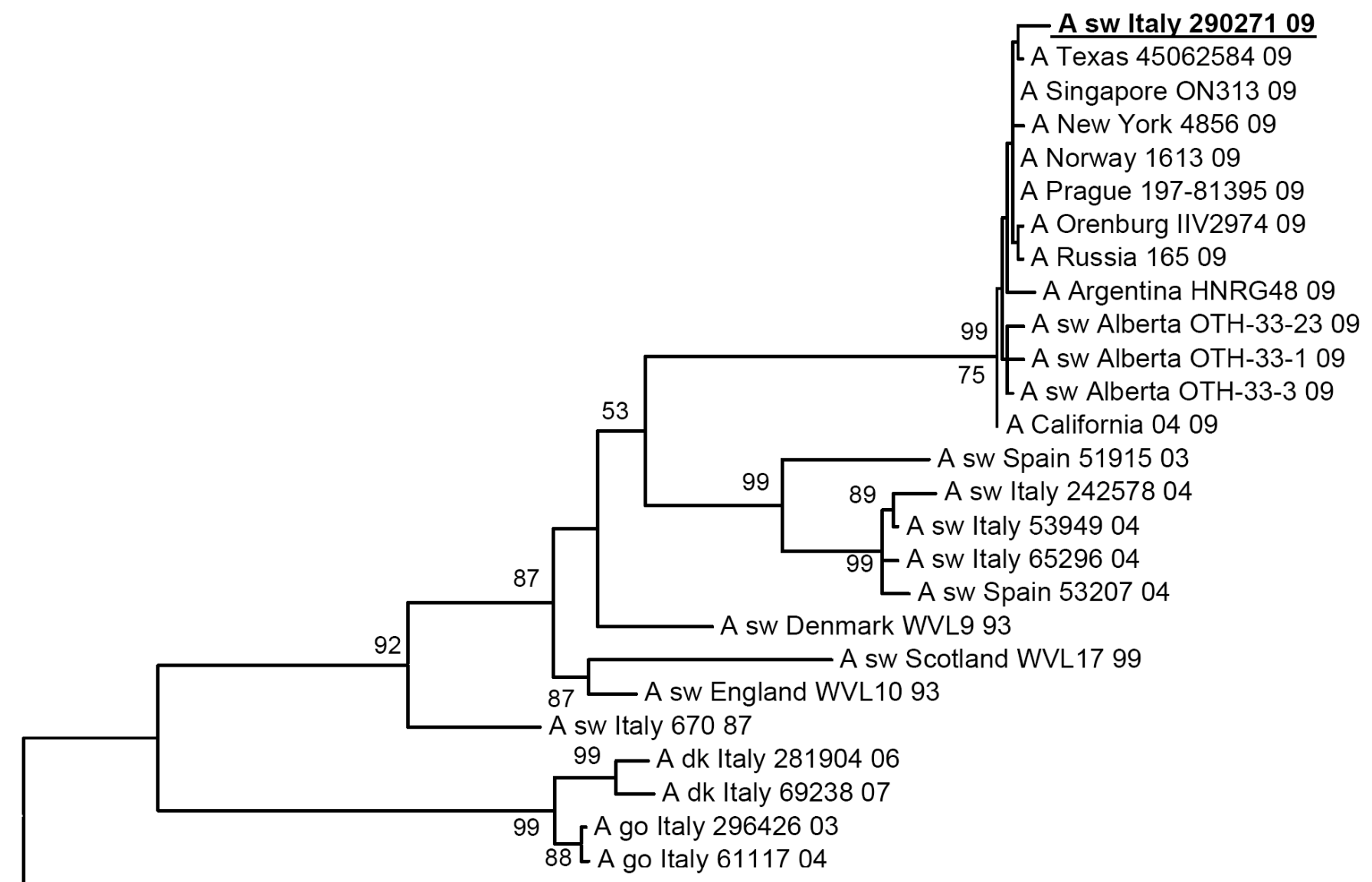

A sw Minnesota 3786699

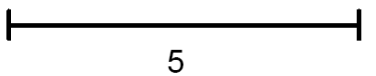

Fig. (2). Phylogenetic relationship of the NA gene of the swine H1N1 pandemic Italian isolate (A/sw/Italy/290271/2009 H1N1) with other Italian SIV and AIV viruses and database retrieved H1N1 swine and human viruses. The unrooted tree was generated as described in the legend of Fig. (1).

from "avian -like" sw/H1N1 viruses detected in Spain and Italy in the last decade [13].

Thirty days after $(\mathrm{H} 1 \mathrm{~N} 1) \mathrm{v}$ diagnosis, sera from 40 sows were collected and tested by HI test performed as described [14] using the following antigens: A/Sw/290271/99 (H1N1)v, A/Sw/Fin/2899/82 H1N1 SIV, A/Sw/It/1521/98 H1N2 SIV and A/Sw/CA/3633/84 H3N2 SIV. Out of these, 20 samples resulted positive to HI test using H1N1v with HI titres from $1 / 10$ to $1 / 80$. All samples resulted negative by $\mathrm{HI}$ vs H1N2 and H1N1 SIVs. Only five animals resulted positive (HI titres from $1 / 20$ to $1 / 80$ ) to H3N2 SIV but were not from the same pigs positive to $(\mathrm{H} 1 \mathrm{~N} 1) \mathrm{v}$. Results of the HI test are reported in Table 1.

This paper reports the first isolation and genomic characterization of $(\mathrm{H} 1 \mathrm{~N} 1) \mathrm{v}$ from a pig farm in Italy. Full sequencing and phylogenetic analysis of $\mathrm{A} / \mathrm{Sw} / \mathrm{It} / 290271 / 09$ confirms a very high similarity throughout the viral genome to the pandemic $(\mathrm{H} 1 \mathrm{~N} 1) \mathrm{v}$. During the epidemiological analysis, the hypotheses of human to pig transmission remained one of the most probable source for the spread of infection because several days before one of the pig farmers showed influenza-like symptoms. Diagnosis of (H1N1)v in the farmer was not possible, due to late swabs sampling and consequently other additional routes of infection can not be excluded. PRRS virus was also detected from the first pool of piglets; PRRS infection is extremely diffused in Italian swine farms and its association with swine influenza in weaning pigs is reported as a common event in the last years [15].

Serological tests evidenced a circulation of H1N1v in the farm since 20 to 40 animals showed $\mathrm{Ab}$ against $(\mathrm{H} 1 \mathrm{~N} 1) \mathrm{v}$ although the HI titres were not very high. Some positive H3N2 sera were also observed in $(\mathrm{H} 1 \mathrm{~N} 1) \mathrm{v}$ negative sows probably due to a H3N2 SIV circulation or an introduction of positive animals in the farm.

Until November 2009, an enhanced monitoring program for swine influenza conducted in Italy, led to the isolation of 53 Swine influenza viruses belonging to the three subtypes currently circulating in Europe (data not shown). Based on these results, it could be assumed that $(\mathrm{H} 1 \mathrm{~N} 1) \mathrm{v}$ was not circulating in the Italian pig population before this reported case. In Italy more than $70 \%$ of the swine industry and over $65 \%$ of poultry farms are located in the Northern part of the country. In addition, in the last ten years, several epidemics of avian influenza H5 and H7 subtypes occurred in the same area involving either domestic or wild birds [16]. In this 
Table 1. Results of the HI Test Performed on Sera From Sows Using Different Antigens. Results are Expressed as HI Titre Reciprocal. Negative Sera are $<10$

\begin{tabular}{|c|c|c|c|c|}
\hline Sera & \multicolumn{4}{|c|}{ HI Antigens } \\
\hline 2 & $\mathrm{~N}$ & $\mathrm{~N}$ & $\mathrm{~N}$ & $\mathrm{~N}$ \\
\hline 3 & $\mathrm{~N}$ & $\mathrm{~N}$ & $\mathrm{~N}$ & $\mathrm{~N}$ \\
\hline 5 & 20 & $\mathrm{~N}$ & $\mathrm{~N}$ & $\mathrm{~N}$ \\
\hline 6 & $\mathrm{~N}$ & $\mathrm{~N}$ & $\mathrm{~N}$ & $\mathrm{~N}$ \\
\hline 7 & 20 & $\mathrm{~N}$ & $\mathrm{~N}$ & $\mathrm{~N}$ \\
\hline 8 & $\mathrm{~N}$ & $\mathrm{~N}$ & $\mathrm{~N}$ & $\mathrm{~N}$ \\
\hline 9 & $\mathrm{~N}$ & $\mathrm{~N}$ & $\mathrm{~N}$ & $\mathrm{~N}$ \\
\hline 13 & 40 & $\mathrm{~N}$ & $\mathrm{~N}$ & $\mathrm{~N}$ \\
\hline 14 & $\mathrm{~N}$ & $\mathrm{~N}$ & $\mathrm{~N}$ & $\mathrm{~N}$ \\
\hline 15 & 10 & $\mathrm{~N}$ & $\mathrm{~N}$ & $\mathrm{~N}$ \\
\hline 16 & 80 & $\mathrm{~N}$ & $\mathrm{~N}$ & $\mathrm{~N}$ \\
\hline 17 & 10 & $\mathrm{~N}$ & $\mathrm{~N}$ & $\mathrm{~N}$ \\
\hline 18 & 20 & $\mathrm{~N}$ & $\mathrm{~N}$ & $\mathrm{~N}$ \\
\hline 19 & 20 & $\mathrm{~N}$ & $\mathrm{~N}$ & $\mathrm{~N}$ \\
\hline 20 & $\mathrm{~N}$ & $\mathrm{~N}$ & $\mathrm{~N}$ & $\mathrm{~N}$ \\
\hline 27 & $\mathrm{~N}$ & $\mathrm{~N}$ & $\mathrm{~N}$ & 80 \\
\hline 28 & 10 & $\mathrm{~N}$ & $\mathrm{~N}$ & $\mathrm{~N}$ \\
\hline 29 & $\mathrm{~N}$ & $\mathrm{~N}$ & $\mathrm{~N}$ & $\mathrm{~N}$ \\
\hline 30 & 20 & $\mathrm{~N}$ & $\mathrm{~N}$ & $\mathrm{~N}$ \\
\hline 31 & $\mathrm{~N}$ & $\mathrm{~N}$ & $\mathrm{~N}$ & $\mathrm{~N}$ \\
\hline 32 & 20 & $\mathrm{~N}$ & $\mathrm{~N}$ & $\mathrm{~N}$ \\
\hline 33 & $\mathrm{~N}$ & $\mathrm{~N}$ & $\mathrm{~N}$ & $\mathrm{~N}$ \\
\hline 34 & $\mathrm{~N}$ & $\mathrm{~N}$ & $\mathrm{~N}$ & $\mathrm{~N}$ \\
\hline 35 & $\mathrm{~N}$ & $\mathrm{~N}$ & $\mathrm{~N}$ & $\mathrm{~N}$ \\
\hline 36 & 10 & $\mathrm{~N}$ & $\mathrm{~N}$ & $\mathrm{~N}$ \\
\hline 37 & 80 & $\mathrm{~N}$ & $\mathrm{~N}$ & $\mathrm{~N}$ \\
\hline 38 & 20 & $\mathrm{~N}$ & $\mathrm{~N}$ & $\mathrm{~N}$ \\
\hline 39 & $\mathrm{~N}$ & $\mathrm{~N}$ & $\mathrm{~N}$ & 80 \\
\hline 40 & 20 & $\mathrm{~N}$ & $\mathrm{~N}$ & $\mathrm{~N}$ \\
\hline
\end{tabular}

context several aspects must be considered also for their implications on human health.
First of all, simultaneous circulation of human, swine and avian influenza viruses in the same area increases the risk of reassortment events, in a susceptible host like swine that may 
function as a reservoir and play a vital role in interspecies transmission of influenza A viruses [17]. Secondly, an improved surveillance programme should be implemented to undertake control measures for limiting the spread of $(\mathrm{H} 1 \mathrm{~N} 1) \mathrm{v}$ in farms and the transmission from animals to humans. Moreover studies on $(\mathrm{H} 1 \mathrm{~N} 1) \mathrm{v}$ sequences should be encouraged in order to monitor constantly any change in viral genotype and evolution of this virus in swine population.

\section{ACKNOWLEDGEMENTS}

We would like to acknowledge Dr. Rosella Petraroli and Ms. Francesca Adella for her valuable technical assistance.

\section{REFERENCES}

[1] Centers for Disease Control and Prevention. Swine influenza A (H1N1) Infection in two children - Southern California, MarchApril 2009. MMWR Morb Mortal Wkly Rep 2009; 58: 400-2.

[2] Schnitzler SU, Schnitzler P. An update on swine-origin influenza virus A/H1N1: a review. Virus Genes 2009; 39: 279-92.

[3] Hofshagen M, Gjerset CEr, Tarpai A, et al. Pandemic influenza A (H1N1) v: human to pig transmission in Norway?. Euro Surveill 2009 [serial on the internet], Nov 2009; [cited 2009 November 12]; 14(45) article 5. Available from: http://www.eurosurveillance. org/ViewArticle.aspx?ArticleId=19406

[4] OIE World Animal Health Information Database: follow up report [serial on the internet]. Influenza A H1N1, Canada: report n.1, June 2009; [cited 2009 June 11]; Argentina: report n.1, July 2009; [cited 2009 July 1]; England: report n.1, Sept 2009; [cited 2009 September 25]; Norway: report n.1, Oct 2009; [cited 2009 October 13]; China: report n.1, Nov 2009; [cited 2009 November 13]; Available from http://www.oie.int/wahis/.

[5] Spackman E, Senne DA, Myers TJ, et al. Development of a realtime reverse transcriptase PCR assay for type A influenza virus and the avian $\mathrm{H} 5$ and $\mathrm{H} 7$ hemagglutinin subtypes. J Clin Microbiol 2002; 40(9): 3256-60.
[6]

Centers for Disease Control and Prevention, CDC protocol of realtime RTPCR for influenza A (H1N1), rev 2. Oct 2009; [cited 2009 October 6]; Available from http://www.who.int/csr/resources/ publications/swineflu/realtimeptpcr/en/index.html

[7] Calsamiglia M, Pijoan C, Trigo A. Application of a nested polymerase chain reaction assay to detect Mycoplasma hyopneumoniae from nasal swabs. J Vet Diagn Invest 1999; 11: 246-51.

[8] Ouardani M, Wilson L, Jetté R, Montpetit C, Dea S. Multiplex PCR for detection and typing of porcine circoviruses. J Clin Microbiol 1999; 37: 3917-24.

[9] Suárez P, Zardoya R, Prieto C, et al. Direct detection of the porcine reproductive and respiratory syndrome (PRRS) virus by reverse polymerase chain reaction (RT-PCR). Arch Virol 1994; 135: 89-99.

[10] Tamura K, Dudley J, Nei M, Kumar S. MEGA4: Molecular Evolutionary Genetics Analysis (MEGA) software version 4.0. Mol Biol Evol 2007; 24: 1596-9.

[11] Chen GW, Shih SR. Genomic signatures of influenza A pandemic (H1N1) 2009 virus. Emerg Infect Dis 2009;15: 1897-903.

[12] Squires B, Macken C, Garcia-Sastre A, et al. Biohealthbase: informatics support in the elucidation of influenza virus host pathogen interactions and virulence. Nucleic Acids Res 2008; 36: D497-503.

[13] Moreno Martin A, Barbieri I, Chiapponi C, et al. Genetic characterization of $\mathrm{H} 1 \mathrm{~N} 1$ and $\mathrm{H} 1 \mathrm{~N} 2$ swine influenza viruses isolated in Italy in 1998-2007: 2008: Proceedings of the $2^{\text {nd }}$ annual meeting EPIZONE (Network of Excellence for Epizootic Disease Diagnosis and Control) "Need for Speed"; 2008 June 4-6; Brescia, Italy; 2005. Available from http: http://www.epizone-eu.net/publ icdocs/Downloads/Abstract\%20book\%20AMweb.pdf

[14] Swine influenza, Ed. OIE Manual of diagnostic tests and vaccines for terrestrial animals, 2004; $5^{\text {th }} \mathrm{Ed}$. Chapter 2.10.11.

[15] Barigazzi G, Donatelli I. Swine influenza in Italy. Vet Res Commun 2003; (Suppl 1): 93-9.

[16] Alexander DJ. An overview of the epidemiology of avian influenza. Vaccine 2007; 25: 5637-44.

[17] Shen J, Ma J, Wang Q. Evolutionary trends of A(H1N1) influenza virus haemagglutinin since 1918. PloS One 2009; 4: e7789. 